\title{
Development of Fermented Mare's Milk Using Mixed Probiotic Cultures
}

\author{
T. W. Murti , E. Robiyati, H. L. Jundi, F. Ramadhani, B. Rustamadji, \& Y. Y. Suranindyah \\ Department of Dairy Science and Milk Industry, Faculty of Animal Science, Gadjah Mada University \\ Jalan Fauna $3^{\text {st }}$ Kampus Bulaksumur Yogyakarta, Indonesia \\ (Received 30-06-2015; Reviewed 19-08-2015; Accepted 15-02-2016)
}

\begin{abstract}
Mare's milk has good nutrient composition for human being in the form of natural milk or milk products. It can be used to replace cow's milk, especially in the regions outside of Java Island which are rarely found dairy cow. This study had an objective to develop fermented mare's milk by using mixed cultures of probiotic bacteria i.e. Lactobacillus acidophilus (A), Bifidobacterium longum (B), and Lactobacillus casei (C). The cultures of two probiotic bacteria $\mathrm{AB}$ and $\mathrm{BC}$ had been developed as well as three probiotic bacteria $\mathrm{ABC}$ culture. The mixed cultures $(\mathrm{AB}, \mathrm{BC}$ and $\mathrm{ABC})$ were prepared in single culture then cultivated in mixed culture as total $10 \% \mathrm{v} / \mathrm{v}$ of mare's milk used and was incubated at $39^{\circ} \mathrm{C}$ for $9 \mathrm{~h}$. The $\mathrm{pH}$, acidity and bacterial count, each of them was analyzed in every $3 \mathrm{~h}$ of incubation time, while the organic acid and sensory tests were conducted at the end of $9 \mathrm{~h}$ of incubation. The results showed that the growth of mixed probiotic bacteria culture BC and $A B C$ had better $\mathrm{pH}$ value that was around 3 compared with $A B$ around 4.5. This showed that the cooperation between bacteria was different in each different combinations. The number of bacteria also increased sharply between 3-6 h of incubation time and 6-9 incubation time (AB and BC) along with the increased lactic acid, but the acetic acid decreased from $1750 \mathrm{mg} / \mathrm{L}$ to $1500 \mathrm{mg} / \mathrm{L}$. The result of sensory test showed low acceptability of trained panelists. It is concluded that mixed cultures, using two or three probiotic bacteria (L. acidophilus, B. longum, and L. casei) could grow in mare's milk. The change of the biochemical patterns indicated a commensalism cooperation among bacteria used. It was therefore the fermented mare's milk using these probiotic bacteria were not well accepted by entrained panelists.
\end{abstract}

Key words: Mare's milk, probiotic mixed cultures, growth condition, biochemical change, sensory test

\section{ABSTRAK}

Susu kuda mengandung komposisi gizi yang baik untuk manusia dalam bentuk susu segar maupun susu olahan. Hal tersebut dapat dimanfaatkan sebagai pengganti susu sapi terutama di daerah luar pulau Jawa yang masih jarang ditemukan sapi perah. Penelitian ini bertujuan untuk mengembangkan susu kuda fermentasi menggunakan kultur bakteri probiotik Lactobacillus acidophilus (A), Bifidobacterium longum (B) dan Lactobacillus casei (C). Kultur campuran (AB, BC, dan ABC) yang diinokulasikan sebanyak $10 \% \mathrm{v} / \mathrm{v}$ dan diinkubasi pada suhu $39^{\circ} \mathrm{C}$ selama $9 \mathrm{jam}$. Nilai $\mathrm{pH}$, kadar keasaman dan jumlah bakteri diuji setiap 3 jam inkubasi sedangkan asam organik dan uji sensoris diuji pada akhir inkubasi. Hasil penelitian menunjukkan bahwa pertumbuhan kultur bakteri probiotik campuran $\mathrm{BC}$ dan $\mathrm{ABC}$ lebih baik dengan nilai $\mathrm{pH}$ akhir berkisar 3 dibandingkan dengan AB yang memiliki pH sekitar 4,5. Hal ini menunjukkan bahwa kerja sama antarbakteri berbeda-beda tiap perbedaan kombinasi. Jumlah bakteri juga meningkat tajam antara jam ke 3-6 waktu inkubasi (ABC) dan jam ke 6-9 waktu inkubasi (AB dan BC) seiring dengan meningkatnya kadar asam laktat, namun kadar asam asetat menurun dari $1750 \mathrm{ke} 1500 \mathrm{mg} / \mathrm{L}$. Hasil uji sensoris menunjukkan bahwa daya terima panelis terhadap semua sampel susu fermentasi yang diuji masih rendah. Dapat disimpulkan bahwa susu kuda fermentasi dengan kultur campuran (L. acidophilus, B. longum, dan $L$. casei) baik dua atau tiga bakteri probiotik dapat tumbuh pada susu kuda. Perubahan biokimia pada susu mengindikasikan adanya kerja sama (kooperasi) antarbakteri yang digunakan namun masih kurang diterima oleh panelis.

Kata kunci: susu kuda, kultur probiotik campuran, pertumbuhan, perubahan biokimia, uji sensoris

${ }^{*}$ Corresponding author:

E-mail: tridjokomurti@yahoo.com 


\section{INTRODUCTION}

Milk is the most nourishing natural biofluid. The bioactives contained in milk includes essential amino acids, specialized casein and peptides, lactalbumins, immunoglobulins, nucleosides, nucleotides, unsaturated and conjugated linoleic acids, sphingomyelins, and fat soluble vitamins and calcium. Mare's milk protein content is higher than that of human's milk and lower than that of cow's milk. Its casein content is also medium, being between that of human's and cow's milks. However, mare's milk fat content is lower than both those of human's and cow's milks (Nikkhah, 2012). Mare's and human's milks are similar in milk fat diglyceride and triglyceride distribution, with polyunsaturated fatty acids (PUFAs) being higher in mare's and human's milks fats than in cow's milk fat. As such, mare's milk is more suitable than cow's milk for human and infant feeding. Mare's milk has a low content of fat but the concentration of lactose is similar to that of human's milk. Mare's milk has a much higher concentration of polyunsaturated fatty acids, especially linoleic and linolenic acids. A very high concentration of vitamin C (4-8 times higher than that in cow's milk) is also found in mare's milk. Based on these characteristic, mare's milk is generally considered more suitable than cow's milk for human nutrition (Malacarne, 2002). An increasing interest has been shown for the use of mare's milk in human nutrition and for treatment of certain human diseases such as hepatitis, chronic ulcer and tuberculosis (Cagno et al., 2004). Despite its composition close to breast milk, mare's milk is seldom consumed in Indonesia. It is therefore to initiate the development of fermented mare's milk.

\section{MATERIALS AND METHODS}

Mare's milk from horse reared at local condition in Segoroyoso-Bantul district was used for media to develop mixed-cultures of probiotic bacteria culture that consisted of Lactobacillus acidophilus (A), Bifidobacterium longum (B) and Lactobacillus casei (C). These three bacteria are considered as lactic acid bacteria (LAB), except bifidobacteria produced acetic acid more than lactic acid (Shah, 2011). The names of mixed cultures were combination of such probiotic bacteria, named as $\mathrm{AB}, \mathrm{BC}$ or ABC. Strain of probiotic bacteria used were $L$. acidophilus FNCC 0051, L. casei FNCC 0090 and B. longum ATCC 15707 and belong to the culture collection of Food and Nutrition Cultures Collection of Universitas Gadjah Mada at Yogyakarta.

Fermented mare's milk cultures were prepared by heating raw milk at $110^{\circ} \mathrm{C}$ for $15 \mathrm{~min}$. The cultures have developed in Dairy Science and Milk Industry Laboratory (ISO 17025:2008) Universitas Gadjah Mada. The mixed cultures $(A B, B C$, and $A B C)$ were prepared in single culture then cultivated in mixed culture as total $10 \% \mathrm{v} / \mathrm{v}$ of mare's milk used. The culture was incubated at $39^{\circ} \mathrm{C}$ for $9 \mathrm{~h}$. The $\mathrm{pH}$, acidity and bacterial count, each of them was analyzed in every $3 \mathrm{~h}$ of incubation time. While the organic acid and sensory tests were conducted at the end of $9 \mathrm{~h}$ of incubation. The $\mathrm{pH}$ was measured with a $\mathrm{pH}$ meter while acidity was measured in $9 \mathrm{~mL}$ of culture after adding $0.5 \mathrm{~mL}$ of a $1 \%$ solution of phenolphthalein in 95\% alcohol, by titrating with $0.1 \mathrm{~N} \mathrm{NaOH}$ (Murti et al., 1993). Total bacteria were enumerated by direct microscopic counting after methylene blue staining according to the method of Breed (Murti et al., 1993). Organic acids was detected by using HPLC-LC column Shin-pack VP-ODS (Shimadzu) at $275 \mathrm{~nm}$ wave length, column temperature at $30^{\circ} \mathrm{C}$, and flow rate $0.4 \mathrm{~mL} / \mathrm{min}$ with methanol $70 \%$ as a mobile phase (Bensmira \& Jiang, 2011). The sensory test was evaluated by using 20 entrained panelists using five scale of intensity or score (Murti et al., 2014).

\section{Statistical Analysis}

One way ANOVA was used to conduct the research which compared the growth of bacteria $(\mathrm{pH}$, acidity and number of total bacteria) as well as the sensory detection of fermented milk. The results were analyzed descriptively and compared to the references.

\section{RESULTS AND DISCUSSION}

The growth of probiotic culture in mare's milk or other milks could be evaluated based on acidity, $\mathrm{pH}$, and number of bacteria. The verification of growth of single cultures during preculture showed a normal growth of probiotics bacteria in mare's milk (Figure 1).

It was quite difficult to differentiate among the species of probiotic used. But, acidophilus species was looked as long chain of bacillus, while L. casei was seen as simple bacillus bacteria. The bifidobacteria presented variety forms either branched, bowling bottle or other irregular bacillus form (Murti et al., 2014). The growth of mixed cultures of $A B, B C$, and $A B C$ are presented in Figure 2 and 3.

The growth of mixed cultures of $\mathrm{BC}$ was similar to that of $\mathrm{ABC}$ based on the reduction of $\mathrm{pH}$ and the increase of acidity. They were more rapid than the culture of AB. The acidity of culture less than 0.4 was considered as low acid, while between 0.4-0.7 was considered as mild acid (Murti et al., 1993).

Total number of bacteria in Figure 3 supported the results indicating the growth of bacteria in all mixed culture. In this figure the growth of mixed probiotic bacteria cultures showed the best in BC mixed culture lead to final $\mathrm{pH}$ around 3 for both mixed cultures $\mathrm{BC}$ and $A B C$, while still around 4.5 in culture $A B$, indicated that cooperation among bacteria differed in different combination. The growth of BC was slightly better than $\mathrm{AB}$ or $\mathrm{ABC}$. Cultures containing L. acidophilus presented the worst growth in these mixed cultures of Mare milk. Despite $\mathrm{pH}$ reached 3 , the acidity of cultures $\mathrm{BC}$ and $\mathrm{ABC}$ were not more than 0.6 equivalent to \% of lactic acid, and considered as mild acid. In all cultures containing bifidobacteria, it was shown the raise of acidity, and the numbers of total bacteria. It is presumed that bifidobacteria has an important role to cooperate with others microbial in mare's milk. It was not clear that cooperation among lactic acid bacteria was the protocooperation mutualistic among species of probiotic bac- 

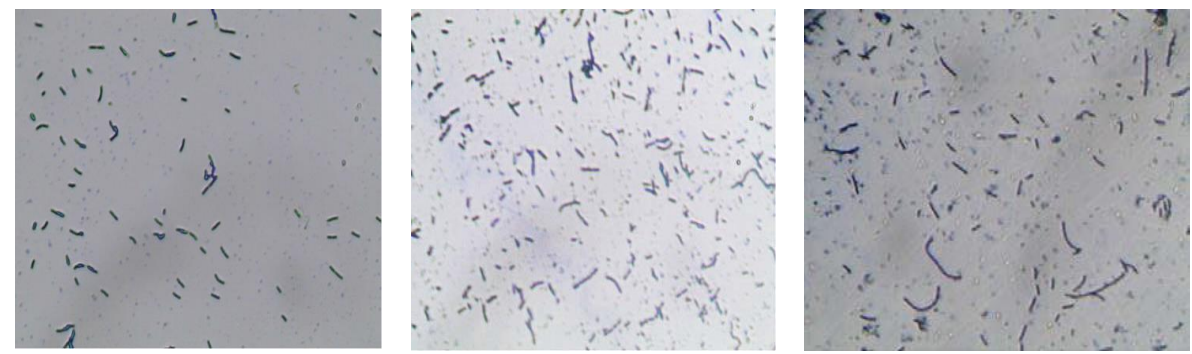

Figure 1. Single culture's of probiotic bacteria in mare milk culture of L. acidophilus (left), Bifidobacterium longum (centre) and L. casei (right).
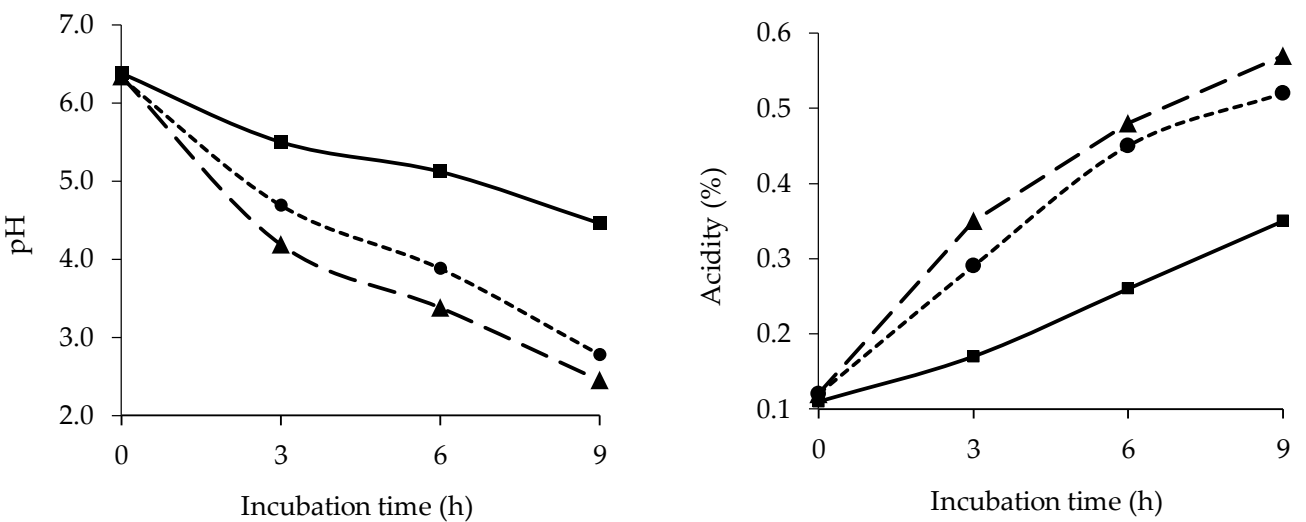

Figure 2. $\mathrm{pH}$ and acidity of mixed cultures of probiotic bacteria in mare milk. $\mathrm{AB}:-\mathbf{-}-; \mathrm{BC}:-\mathbf{\Lambda}-; \mathrm{ABC}:-\bullet-; \mathrm{A}=$ L. acidophilus, $\mathrm{B}=$ Bifidobacterium longum, $\mathrm{C}=$ L. casei.
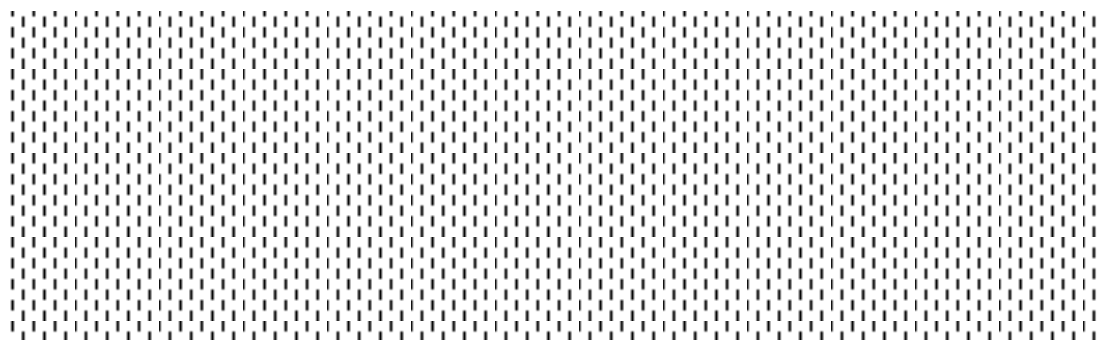

Figure 3. Mixed cultures of $\mathrm{AB}$ (left), $\mathrm{BC}$ (centre), and $\mathrm{ABC}$ (right) in mare milk. $\mathrm{A}=$ L. acidophilus, $\mathrm{B}=$ Bifidobacterium longum, $\mathrm{C}=$ L. casei .

teria involved or just commensalism, which positively affected for one species of them without reducing the others (Murti, 1993).

Angelov (2009) stated that protocooperation among bacteria were numbers detected in Yoghurt, in which two species involved give positive impact for each others. Most of the researches about protocooperation were justified only by using yoghurt bacteria which involved only two species, i.e. Streptococcus thermophilus and Lactobacillus bulgaricus.

Therefore, it is interesting to see such type of relation among more than two kinds of LAB species. The growth of LAB was also shown by production of organic acids. The presence of bifidobacteria resulted acetic acid (Figure 4) which increased during incubation in $\mathrm{AB}$ but decreased in other cultures. Cultures $\mathrm{AB}$ produced the same amount of lactic acid with the others that was $500 \mathrm{mg} / \mathrm{L}$ and the culture ABC produced acetic acid highest among the others. The quantity of lactic acid raised during incubation.

It was resumed that Bifidobacteria was the most adapted for growing well in mare milk, either in single culture or in mixed culture especially in cooperation with $L$. casei. Up to this step, it is not clear whether the symbiotic relationship between two or three species will give more mutual metabolism with positive effects on the fermented products. Either a protocooperation type or commensalism which positive impact for one species but not for the other as well as symbiotic mutualism cooperation which both species have taken the advantage from each other.

Proto-cooperation between these two LAB species in yoghurt was the main interaction determined the fermentation process and product quality, as stated by 

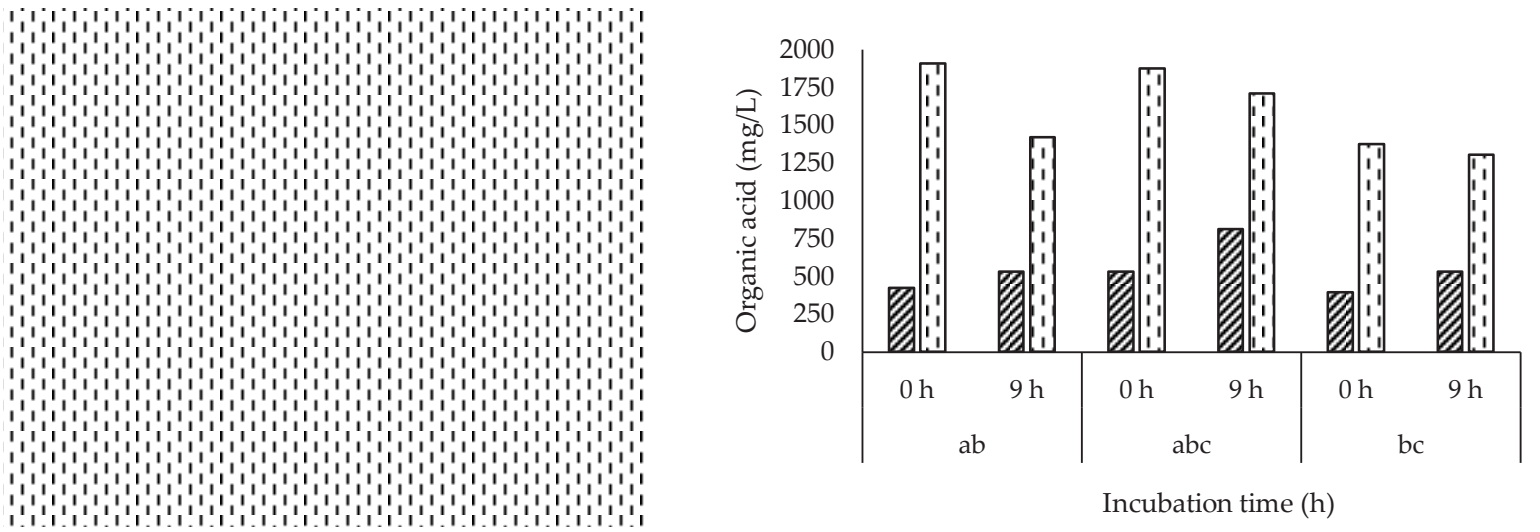

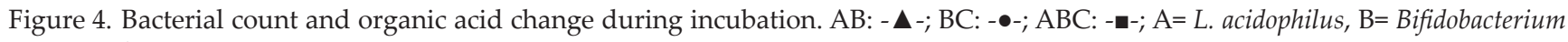
longum, $\mathrm{C}=$ L. casei; $\boldsymbol{\nabla}$ lactic acid $\boldsymbol{\square}$ acetic acid

Angelov et al. (2009). However symbiotic, protocooperation, or associative growth are a term for two species, especially in yoghurt, but a term for more than two species of bacteria as in these cases has not been mentioned yet.

The ABC culture in Figure 4 showed a rapid growth for 3 to 6 hours of incubation to reach $1.4 \times 10^{9}$ bacteria/ $\mathrm{mL}$ at $9 \mathrm{~h}$ and the lactic acid content raised from 500 to $750 \mathrm{mg} / \mathrm{L}$, while in the other cultures grew rapidly between 6 to $9 \mathrm{~h}$ of incubation and grew slowly from 300 to $500 \mathrm{mg} / \mathrm{L}$, these were equal to acidity. At the other side, the content of acetic acid reduced after $9 \mathrm{~h}$ of incubation from 1,800 mg/L in cultures $A B$ and $A B C$ to 1,350 in culture $A B$ and to $1,600 \mathrm{mg} / \mathrm{L}$ in culture $A B C$, while from 1,300 to $1,250 \mathrm{mg} / \mathrm{L}$ in culture $\mathrm{BC}$. The high content of acetic acid was due to the role of bifidobacteria. The high content of acetic acid indicated the early role of bifidobacteria in mixed cultures for supporting others. $L$. acidophilus and L. casei were homofermentative bacteria in pure culture or in co-culture produced the largest amount of lactic acid using the Embden-MeyerhofParnas pathway (glycolysis) (Rodrigues et al., 2011). B. longum was a heterofermentative strain that fermented lactose through a specific route called bifidus pathway, which was characterized by the presence of the enzyme fructose 6-phosphate phosphoketolase. Theoritically, the fermentation of two glucose molecules leads to 3 molecules of acetic acid and 2 molecules of lactic acid. This phenomenon contributed to the sensory quality (Oliviera et al., 2012; Casarotti et al., 2014).

Free protein in fermented mare's milk after 3 hours of incubation found the biggest in mixed culture of $\mathrm{ABC}$, followed by culture $\mathrm{BC}$ and $\mathrm{AB}$ by $6.91 ; 4.42$; and $5.20 \mathrm{mg} / \mathrm{mL}$, respectively, as compared to $3.52 \mathrm{mg} / \mathrm{mL}$ in raw milk. All of probiotic mixed cultures presented more free amino acids than in raw's milk indicating the growth of bacteria.

The major differences among the samples of fermented milk were observed in the case of acceptability and flavor attributes. Flavor was one of the most important properties of food acceptability and consumer preference (Cheng, 2010).

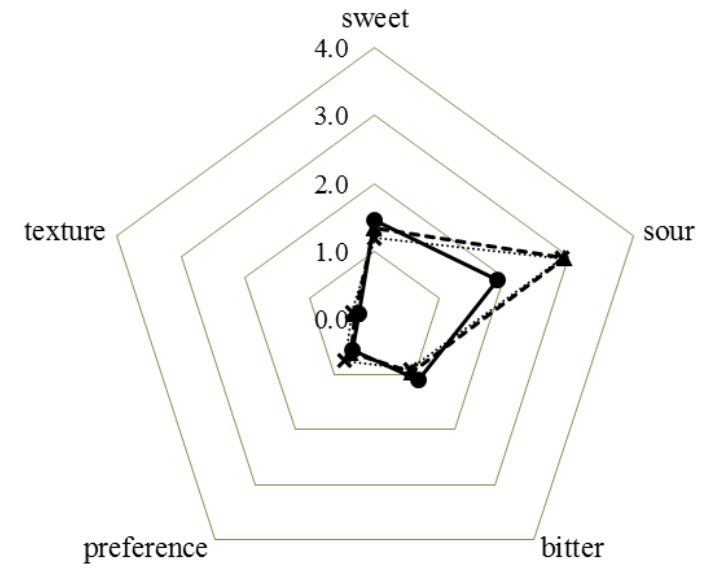

Figure 5. Sensorial attributes of mixed probiotic fermented

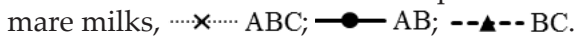

The sensory profile of fermented milk is directly influenced by the metabolic activity of the bacteria, which interact strongly with the components of the media to convert certain metabolic products during the growth, particularly organic acids and free amino acids (Serra et al., 2009). Some of free amino acids present bitterness, while others influence sweetness of products. Therefore, the profile of amino acid as well as it's quantity could be used to explain the sensory of product in Figure 5, lead to acceptance of consumers. All panelist considered that probiotic fermented mare's milk had low score of consumers acceptance. Sour taste of fermented BC and ABC was more acid than $A B$ after $9 \mathrm{~h}$ of incubation, while sweetness and bitterness was considered low.

\section{CONCLUSION}

Mixed cultures of probiotic bacteria of L. acidophilus, B. longum, and L. casei in mixed of two or three bacteria grown in mare's milk lead to change biochemical profile. The combination of probiotic bacteria have to be considered for fermented mare's milk as they can influence the characteristics of the product. 


\section{ACKNOWLEDGEMENT}

We present special thank for Maurinda Safitri and Widitya Tri Nugraha for their contribution.

\section{REFERENCES}

Angelov, M., G. Kostov, E. Simova, D. Beskova, \& P. Koprinkova-Hristova. 2009. Proto-cooperation factors in yogurt starter cultures. Revue de genie industriel 3: 4-12. http://www.revue-genie-industriel.info/ (18 Desember 2015)

Bensmira, M. \& B. Jiang. 2011. Organic acid formation during the production of a novel peanut-milk kefir beverage. Brit. J. Dairy Sci. 1: 18:22.

Casarotti, S. N., D. A. Monteiro, M. M. S. Moretti, \& L. B. P. Ana. 2014. Influence of the combination of probiotic cultures during fermentation and storage of fermented milk. Food Res. Int. 59: 67-75. http://dx.doi.org/10.1016/j. foodres.2014.01.068

Cheng, H. 2010. Volatile flavor compounds in yogurt. Cr. Rev. Food Sci. 50: 938-950. http://dx.doi. org/10.1080/10408390903044081

Di Cagno, R., A. Tamborrino, G. Gallo, C. Leone, M. De Angelis, \& M. Faccia. 2004. Uses of mare's milk in manufacture of fermented milk. International Dairy Journal 14:767-775.

Malacarne, M., F. Martuzzi, A. Summer \& P. Mariani. 2002. Protein and fat composition of mare's milk: some nutritional remarks with reference to human and cow's milk.
Int. Dairy J. 12: 869-877. http://dx.doi.org/10.1016/S09586946(02)00120-6

Murti, T. W., C. Bovillane, M. Landon, \& M. J. Desmazeaud. 1993. Bacterial growth and volatile compounds in yogurt-type products from soy milk containing $\mathrm{Bi}$ fidobacterium Ssp. J. Food Sci: 153-157. http://dx.doi. org/10.1111/j.1365-2621.1993.tb03233.x

Murti, T. W. 2014. Food, Diet, and Milk Technology. Gadjah Mada University Press, Yogyakarta.

Nikkhah, A. 2012. Equidae milk promises substitutes for cow and human breast milk. Turk. J. Vet. Anim. Sci. 36: 470-475.

Oliveira, R. P. S., P. Perego, M. N. Oliveira, \& A. Converti. 2012. Growth, organic acids profile and sugar metabolism of Bifidobacteriumlactis in co-culture with Streptococcus thermophilus: The inulin effect. Food Res. Int. 48: 21-27. http://dx.doi.org/10.1016/j.foodres.2012.02.012

Rodrigues, D., T. A. P. Rocha-Santos, C. I. Pereira, A. M. Gomes, F. X. Malcata, \& A. C. Freitas. 2011. The potential effect of FOS and inulin upon probiotic bacterium performance in curdled milk matrices. LWT-Food Sci. Technol. 44: 100-108.

Serra, M., A. J. Trujillo, B. Guamis, \& V. Ferragut. 2009. Flavour profiles and survival of starter cultures of yoghurt produced from high-pressure homogenized milk. Int Dairy J. 19: 100-106. http://dx.doi.org/10.1016/j.idairyj.2008.08.002

Shah, N. P. 2011. Bifidobacterium spp.: Morphology and Physiology. In: J. W. Fuquay, P. F. Fox, \& P. L. H. McSweeney (Eds.). Encyclopedia of Dairy Sciences. 2nd ed. Vol. 3. Elsevier. http://dx.doi.org/10.1016/B978-0-12-374407-4.00043-1 